\title{
Structure and Specificity of T Cell Receptors Expressed by Potentially Pathogenic Anti-DNA Autoantibody-inducing T Cells in Human Lupus
}

\author{
Ami Desai-Mehta, ${ }^{\star \ddagger}$ Changchuin Mao, ${ }^{\ddagger}$ Sumati Rajagopalan, ${ }^{\ddagger}$ Tonya Robinson, ${ }^{\star}$ and Syamal K. Datta* \\ *The Departments of Medicine and Microbiology-Immunology, Northwestern University Medical School, Chicago, Illinois 60611; and \\ ${ }^{\ddagger}$ Sackler Immunology Programme, Tufts University School of Medicine, Bostcn, Massachusetts 02111
}

\begin{abstract}
The production of potentially pathogenic anti-DNA autoantibodies in SLE is driven by special, autoimmune $T$ helper (Th) cells. Herein, we sequenced the $T$ cell receptor (TCR) $\alpha$ and $\beta$ chain genes expressed by 42 autoimmune Th lines from lupus patients that were mostly CD4+ and represented the strongest inducers of such autoantibodies. These autoimmune TCRs displayed a recurrent motif of highly charged residues in their CDR3 loops that were contributed by $\mathrm{N}$ nucleotide additions and also positioned there by the recombination process. Furthermore, Th lines from four of the five patients showed a marked increase in the usage of the Va8 gene family. Several independent Th lines expressed identical TCR $\alpha$ and/or $\beta$ chain sequences indicating again antigenic selection. 10 of these Th lines could be tested further for antigenic specificity. 4 of the 10 pathogenic antiDNA autoantibody-inducing Th lines responded to the nonhistone chromosomal protein HMG and two responded to nucleosomal histone proteins; all presented by HLA-DR molecules. Another Th line responded to purified DNA more than nucleosomes. Thus, these autoimmune Th cells of lupus patients respond to charged epitopes in various DNA-binding nucleoproteins that are probably processed and presented by the anti-DNA B cells they selectively help. $(J$. Clin. Invest. 1995. 95:531-541.) Key words: systemic lupus erythematosus - T cell receptors • anti-DNA autoantibodies - autoimmune diseases $\bullet$ helper-inducer $T$ lymphocytes
\end{abstract}

\section{Introduction}

Lupus nephritis in humans, as in mice, is associated with the spontaneous production of pathogenic anti-DNA autoantibodies that are IgG in class and cationic in charge (1-7). B cells producing these autoantibodies in active lupus appear to be selected by some autoantigen(s) - since they show evidence of clonal expansion $(1,6)$ as well as somatic mutations that generate cationic residues in their autoantibody $\mathrm{V}$ regions (for reviews see reference $8-10$ ). The production of these potentially patho-

Address correspondence to Dr. Syamal K. Datta, Arthritis Division, Ward 3-315, Northwestern University School of Medicine, 303 East Chicago Avenue, Chicago, IL 60611-3008. Phone: 312-503-8003; FAX: 312-503-0994.

Received for publication 15 August 1994 and in revised form 6 October 1994.

J. Clin. Invest.

(C) The American Society for Clinical Investigation, Inc.

0021-9738/95/02/0531/11 \$2.00

Volume 95, February 1995, 531-541 genic autoantibodies is driven by certain $\mathrm{T}$ helper $(\mathrm{Th})^{1}$ cells that are detectable in patients with active lupus nephritis, but not in normal subjects or lupus patients in remission (1). Although the antigenic specificities of these $T$ cells were unknown, we isolated these Th cell lines in vitro by selecting for their special functional properties $(1,11)$. Among $396 \mathrm{~T}$ cell lines that were established by limiting dilution cultures of the spontaneously activated $\mathrm{T}$ cells from five patients with lupus nephritis, only $59(\approx 15 \%)$ had the ability to selectively augment the production of potentially pathogenic anti-DNA autoantibodies when cultured with autologous B cells (11). Therefore, these autoantibody-inducing Th cells of lupus are a special group of autoimmune $\mathrm{T}$ cells that are distinct from conventional "autoreactive" $T$ cells. Although certain double negative (CD4-/CD8-) Th cells, as well as certain CD8 + Th cells, are important components of this autoantibody-inducing $T$ cell population, their contribution is probably secondary in SLE $(1,11-13)$. The CD4+ Th cells might be the prime movers in the pathogenic autoimmune response, since they are most prevalent among the autoimmune Th clones (49 out of 59) and they also are the strongest helpers, increasing IgG anti-DNA autoantibody production up to 250 -fold when cocultured with autologous B cells (11). To determine the basic mechanism of the pathogenic autoimmune response in human SLE, the structure and antigenic specificity of the receptors expressed by these spontaneously arising autoimmune Th cells have to be analyzed first. Herein, we determined the sequences of the $\alpha$ and $\beta$ chain TCR genes expressed by these lupus Th cells and analyzed their specificity for some candidate autoantigens.

\section{Methods}

Patients and $T$ helper cell lines. The patients with active lupus nephritis and their HLA-typing (serological) results were described $(1,11)$. HLA class II molecular typing using EBV-transformed B cell lines (EBVBCL) from the patients was performed by Dr. Juan Yunis (Dana Farber Cancer Institute, Boston, MA) as shown in Table I.

The $T$ helper cell lines that preferentially induce the production of potentially pathogenic anti-DNA autoantibodies by autologous B cells were derived from peripheral blood mononuclear cells of these five active-lupus patients as described $(1,11)$. The $T$ cell lines were tested for help in the production of cationic IgG class anti-DNA autoantibodies within 6-8 wk after initiation of the limiting dilution cultures $(1,11)$.

Sequence analysis of TCR $\alpha$ and $\beta$ chain genes expressed by $T$ helper cell lines. Total RNA extracted from each Th cell line was reverse transcribed using oligo (dT) primer as described $(12,14,15)$. The cDNA was amplified in two stages using TCR V region consensus primer and

1. Abbreviations used in this paper: APC, antigen-presenting cell; dsDNA, double-stranded DNA; EBV-BCL, EBV-transformed B cell line; HMG, high mobility group of nonhistone chromosomal proteins; HSP, heat shock protein; SI, stimulation index; snRNP, small nuclear ribonucleoprotein; TCR, $\mathrm{T}$ cell receptor; $\mathrm{Th}, \mathrm{T}$ helper cell. 
Table I. Molecular Typing of Lupus Patient's MHC Class II

\begin{tabular}{|c|c|c|c|c|c|c|c|c|c|}
\hline Patient & 1.DQA1 & 2.DQA1 & 1.DRB1 & 2.DRB 1 & DRB3 & DRB4 & DRB5 & 1.DQB1 & 2.DQB1 \\
\hline JCA & 0102 & 0301 & 02 & 09 & 0101 & 0101 & 0101 & 0602 & 0201 \\
\hline MCM & 0101 & 0501 & 0102 & 11 & 02 & - & - & 0501 & 0301 \\
\hline DS-2 & 0101 & 0501 & 0101 & 0301 & 0101 & - & - & 0501 & 0201 \\
\hline SE-2 & 0501 & - & 0301 & - & 0101 & - & - & 0201 & - \\
\hline HS-2 & 0102 & 0301 & 02 & 04 & - & 0101 & 0101 & 0602 & 0302 \\
\hline
\end{tabular}

nested C region primers. For stage I PCR (20 cycles), $20 \mu 1$ of cDNA was amplified using $40 \mathrm{pmol}$ each of $5^{\prime} \mathrm{V} \beta$ or $\mathrm{V} \alpha$ consensus primer (sense) with EcoRI site and 3' $\mathrm{C} \beta$ or $\mathrm{C} \alpha$ external primer (antisense) for TCR $\beta$ and $\alpha$ chains, respectively, as described $(16,17)$. The stage II amplification ( 25 cycles) was performed with 1-2 $\mu$ l (for TCR $\beta$ chain) or 2-5 $\mu \mathrm{l}$ (for TCR $\alpha$ chain) of stage I reaction product using 100 pmol each of $5^{\prime} \mathrm{V} \beta$ or $\mathrm{V} \alpha$ consensus primer and $3^{\prime} \mathrm{C} \beta$ or $\mathrm{C} \alpha$ internal primer (antisense) with EcoRI site, as described $(16,17)$.

The amplified cDNA product of expected size was gel-purified, digested with EcoRI, purified further and cloned into puc19, and sequenced with $\mathrm{C} \beta$ internal or $\mathrm{C} \alpha$ internal primers, as described $(12,14$, 15). From two to nine independent colonies were sequenced from each TCR cDNA amplification product. Independent verification of TCR sequences was obtained in some cases by using a linker-ligated PCR technique (15). Only the functional TCR $\alpha$ chain sequences are shown in the results section. Two in-frame (functional) TCR $\alpha$ chain sequences were obtained in seven Th lines (see Results), whereas in the other Th lines a single functional $\alpha$ chain sequence with or without a second out of frame sequence (not shown) was obtained. The identities of TCR gene family sequences obtained here were established by comparing them with published sequences (18-25)

Antigens. High mobility group (HMG) chromosomal proteins containing HMG-1, 2, 14, and 17 were prepared and purified from fetal calf thymus using the $5 \%$ perchloric acid extraction method as described (26). Protein concentration of the HMG preparation was estimated by BCA kit (Pierce, Rockford, IL). To prepare HMG/DNA complex, HMG and purified double-stranded (ds) DNA from calf thymus (Sigma Chemical Co., St. Louis, MO) were combined together at $0.1: 1$ or 1:1 ratios, rocked overnight at $4 \mathrm{C}$ before addition into the antigen-specific proliferation assays. Purified recombinant HMG-1 and HMG-17 proteins were obtained from Dr. Stephen Lippard (Massachusetts Institute of Technology, Cambridge, MA) and Dr. Michael Bustin (National Institutes of Health, Bethesda, MD) $(27,28)$. Mononucleosomes (Nuc) were prepared as described (29). Nucleohistones containing polynucleosomes (Sigma Chemical Co.), heparan sulphate (Sigma Chemical Co.), purified histones H2A, H2B, H3, and H4 (Boehringer Mannheim Co., Indianapolis, IN), small nuclear ribonucleoprotein (snRNP) extract (Chemicon International, Inc., Temecula, CA), and the heat shock proteins HSC 70 and HSP 90 (StressGen Biotechnologies Corp., Victoria, British Columbia, Canada)were also used as antigens in $\mathrm{T}$ cell proliferation assays.

$T$ cell proliferation assays. The Th cell lines were maintained by addition of irradiated (3,000 rad) autologous EBV-BCL once a week and rIL-2 $(20 \mathrm{U} / \mathrm{ml})$ twice a week. These lines were rested 7-10 d before proliferation assay. $2 \times 10^{4}$ Th line cells were cocultured in triplicate with $4 \times 10^{4}$ irradiated (3,000 rad) antigen-presenting cells (APC) that were either subclones of autologous EBV-BCLs from lupus patients or normal, HLA-matched EBV-BCL, Boleth (a gift from Dr. Juan Yunis), in a final volume of $200 \mu$ l of RPMI 1640 supplemented with $10 \%$ human AB serum (Pel-Freez Biologicals, Brown Deer, WI) using round-bottomed 96-well plates (Nun, Roskilde, Denmark). The Boleth EBV-BCL line was DRB1*0401, DRB4*0101. Since this HLADR was shared between Boleth and lupus patient HS-2 and Boleth EBV-BCL by itself did not stimulate the DR-restricted Th cell lines from HS-2, thus lowering background stimulation, Boleth could be used as additional APC for the Th lines from HS-2. In case of the other Th lines as well as those from HS-2 patient, subclones of the original autologous EBV-BCL (11) were used as APC, as these subclones by themselves did not stimulate the Th cell lines significantly above background levels. The EBV-BCL were either pulsed with antigen (10-20 $\mu \mathrm{g} / \mathrm{ml}$ ) for $3.5 \mathrm{~h}$ at $37 \mathrm{C}$ in serum-free medium or antigen was added in continuous culture $(1-10 \mu \mathrm{g} / \mathrm{ml})$. The cultures were pulsed with $1 \mu \mathrm{Ci}$ / well of $\left[{ }^{3} \mathrm{H}\right]$ thymidine during the final $18 \mathrm{~h}$ of the $90-\mathrm{h}$ assay. The plates were harvested and incorporated radioactivity was measured. The results were also expressed as stimulation index (SI), which was calculated by dividing the mean counts per minute incorporated by $\mathrm{T}$ cells cultured with APC plus antigen by the mean counts per minute of $\mathrm{T}$ cells cultured with APC alone.

$H L A$ restriction analysis of $T$ helper cell lines. Antigen-specific proliferation of the Th cells was blocked using a panel of monoclonal antibodies (mAb) to HLA class II molecules. B7/21 (anti-DP) and L243 (anti-DR) antibodies (Becton Dickinson, San Jose, CA) were used at 1 $\mu \mathrm{g} / \mathrm{ml}$, and Genox 3.53 (anti-DQ), 9.3F10 (anti-DR, -DQ), and IV A12 (anti-DP, -DR) obtained from American Type Culture Collection (Rockville, MD) were used at $2.5 \mu \mathrm{g} / \mathrm{ml}$. The ATCC mAbs were concentrated from hybridoma supernatants using $47 \%$ saturated ammonium sulphate and dialyzed before use.

\section{Results}

$T$ cell receptor $\alpha$ and $\beta$ chain sequences. The deduced amino acid sequences of TCR $\alpha$ and $\beta$ chain genes used by 42 of the potentially pathogenic autoantibody-inducing Th cell lines that we had derived from 5 patients with lupus nephritis (11) are shown in Figs. 1-5. All of these autoimmune Th lines were CD4+ except two that were CD4-/CD8- or double negative (DN). Fig. 1 shows the TCR sequences of the autoimmune Th lines from lupus patient JCA. The ability of these Th lines to selectively augment the production of IgG anti-DNA autoantibodies when cocultured with autologous $B$ cells was determined in a previous study (11) and is included in all of the figures for easy reference. Overall, the TCR sequences of the lupus Th lines including their junctional regions were heterogeneous. But the CDR3 loops of all these TCRs contained charged residues. Th lines JC2, JC3, JC5, JC11, and JC16 had predominantly negatively charged residues in CDR3 of their TCR $\beta$ chains but positively charged residues were present in their $\alpha$ chain CDR3. The TCR CDR3 of the other Th clones from this patient contained both positive and negatively charged residues. In all of these autoimmune TCR $\beta$ chains, a negative residue in their $\mathrm{CDR} 3$ loops was contributed by the $\mathrm{J} \beta$ segment due to the nature of the joining process. Moreover, in five of the nine TCR $\beta$ chains sequenced, one or more charged residue(s) in their junctional regions were generated by $\mathrm{N}$-nucleotide additions as deduced from their nucleotide sequences (deposited in GenBank). Even after sequencing multiple PCR products from each line, only one functional TCR $\beta$ chain was found to be expressed 


\begin{tabular}{|c|c|c|c|c|c|c|c|c|c|}
\hline $\mathrm{T}_{\mathrm{H}}$ Line & $\mathrm{V} \beta$ & Junction & $\mathrm{J} \beta$ & $\begin{array}{l}V \beta / J \beta \\
\text { genes }\end{array}$ & $\mathrm{V} \boldsymbol{\alpha}$ & Junction J $\alpha$ & $\begin{array}{l}V \alpha / J \alpha \\
\text { genes }\end{array}$ & $\frac{\text { Fold In }}{\alpha \text {-dsDNA }}$ & $\frac{\text { crease }^{\star}}{\alpha-\text { ssDNA }}$ \\
\hline \multicolumn{10}{|c|}{ Patient JCA: } \\
\hline JC11 & $\operatorname{CsA}$ & R $\rightarrow$ IRAGG & TËTQYFGP & $2.1 / 2.3$ & CAA & PVGNNGLAFGKG & $8.1 / a 11$ & 125.6 & 4.0 \\
\hline JC5 & $\operatorname{CSA}$ & RmPLAGG & TETQYFGP & $2.1 / 2.3$ & CAAS & KPGGRLIFGQG & $21.1 a / 8$ & 30.0 & 4.0 \\
\hline JC16 & CASSL & DPGAL & TGBLFGE & $6.6 / 2.2$ & CAV & NSGGSNYRLTFGKG & $15.1 / 11$ & 41.7 & 5.0 \\
\hline JC3 & cAss & FVYLSGLAGP & ITQYFGP & $8.1 / 2.3$ & CAAS & KGSTLGRLYFGRG & $8.1 / 17$ & 200.0 & 11.0 \\
\hline JC2 & CASS & FVYLSGLAGP & BTQYFGP & $8.1 / 2.3$ & $\begin{array}{l}\text { CAAS } \\
\text { CAA }\end{array}$ & $\begin{array}{l}\text { Ki.GSTLGRLYFGRG } \\
\text { PVGNNRLAFGKG }\end{array}$ & $\begin{array}{l}8.1 / 17 \\
8.1 / a 11\end{array}$ & 27.0 & 2.0 \\
\hline JC18 & $\mathrm{cs}$ & LGLAGIP & BTQYFGP & $4.1 / 2.3$ & $\mathrm{CA}$ & FNIRGSNYRLTFGKG & $8.2 / 11$ & 83.0 & 7.0 \\
\hline JC9 & CASSL & ARVGGN & TETQYFGP & $6.2 / 2.3$ & CAV & NAGTASKLTFGTG & $2.2 / A A 17$ & 15.6 & 4.9 \\
\hline JC14 & CASS & SQTRAF & QETQYFGP & $5.2 / 2.5$ & & n.d. & & 31.3 & 12.0 \\
\hline JD5 & $\mathrm{CA}$ & TRGRAWG & TMAFFGQ & $17.1 / 1.1$ & & n.d. & & 250.0 & 13.0 \\
\hline JD22 & & & n.d. & & $\begin{array}{l}\text { CAA } \\
\text { CAAS }\end{array}$ & $\begin{array}{r}\text { PGYSNASKIIFGSG } \\
\text { AMYSGGGABGLTFGKG }\end{array}$ & $\begin{array}{c}8.1 / 1 \\
21.1 a / 23\end{array}$ & 16.5 & 19.0 \\
\hline
\end{tabular}

Figure 1. Junctional region sequences ${ }^{2}$ of TCR $\alpha$ and $\beta$ chains expressed by the potentially pathogenic, anti-DNA autoantibody-inducing Th cell lines from lupus patient JCA. The following statements apply to Figs. 1-5. The sequences are shown in single letter amino acid code and only those positively $(\mathrm{R}, \mathrm{K}, \mathrm{H})$ and negatively $(\mathrm{D}, \mathrm{E})$ charged residues that are located within the CDR3 loops are highlighted. The CDR3 loops extend from positions 93-104 and 95-106 for TCR $\alpha$ and $\beta$ chains, respectively, the conserved cysteine (C) in the 3' end of V $\alpha$ being at position 90 and that in $\mathrm{V} \beta$ at position $92(40)$. The identities of $\mathrm{V}$ and $\mathrm{J}$ genes for the TCR were established from published sequences $(18-25)$ and $\mathrm{V} \alpha / \mathrm{J} \alpha$ nomenclature or numbering is according to references 18 and 20, unless otherwise specified. All of the V $\alpha 8.1$ sequences in these lupus Th clones have an $\mathrm{R} \rightarrow \mathrm{A}$ substitution at position 63 as compared with the sequence reported in reference 18 . n.d., not determined. $*$ Data from reference 11 , showing help provided by the Th line to autologous B cells to produce IgG anti-DNA autoantibodies, expressed as fold increase over the production by the B cells cultured by themselves. A ".-" sign means there was no further augmentation of the autoantibody production when the Th cells were cultured with the B cells. In this Figure, Th line JC16 has the $\mathrm{V} \alpha 15.1$ sequence matching that of AC24 in reference 23 . The J $\alpha$ sequences in Th lines JC2 and JC11 matched with sequences identified as IGRJa11 in reference 24, and therefore they are designated as $a 11$. The J $\alpha$ sequence of Th line JC9 matched AA17 sequence in reference 23.

by each Th line, except JD22 whose TCR $\beta$ chain sequence could not be determined. This observation is consistent with these Th lines being clonal, since they were derived by limiting dilution cultures. Th lines JC2 and JD22 expressed two in-frame TCR $\alpha$ chain mRNA, probably due to the frequent lack of allelic exclusion of TCR $\alpha$ at the message level (30). Nevertheless, the second TCR $\alpha$ chain sequence in other Th clones was found to be out-of-frame or nonfunctional (not shown). Remarkably, Th lines JC2 2 and JC3 shared identical TCR $\alpha$ and $\beta$ chain sequences, although the former had an additional TCR $\alpha$ message that was in-frame. Th lines JC5 and JC11 had identical TCR $\beta$ chains but different $\alpha$ chains. Approximately 67\% (6 out of 9) of the Th lines used $\mathrm{J} \beta 2.3$, much more frequently than its expression range of $7-15 \%$ in peripheral blood $\mathrm{T}$ cells of normal subjects (31). Finally, a member of the $\mathrm{V} \alpha 8$ gene family was also more frequently used by the autoantibody-inducing Th lines of this lupus patient JCA: $\approx 63 \%$ ( 5 out of 8 ) of the lines expressed $\mathrm{V} \alpha 8$ as compared with an expression level of $\approx 9.1 \%(31,32)$ in normal $\mathrm{T}$ cells.

2. The sequences shown in Figs. 1-5 have been submitted to GenBank. Accession numbers are U12318, U12319, and U14013-U14099.
Fig. 2 shows the TCR $\alpha$ and $\beta$ chain sequences of autoantibody-inducing Th lines from the lupus patient MCM. Again, the TCR sequences are heterogeneous with charged residues prominent in their CDR3 loops, which were contributed by $\mathrm{N}$ nucleotide additions, as well as being positioned there from $\mathrm{J}$ segments due to the nature of the recombination process. Among these Th lines, MD32 and MC13 share identical TCR $\beta$ chains, but their TCR $\alpha$ chains are different. Moreover, MC13 Th line expressed a second TCR $\beta$ chain. This line is probably biclonal, since out of nine TCR $\beta$ cDNA-PCR products sequenced, five had one of the sequences and four had the other. Allelic exclusion of TCR $\beta$ message is quite rigorous in contrast with $\alpha$ chains (30). Approximately 38\% (3 out of 8) of the Th lines in this patient expressed $\mathrm{V} \alpha 15.1$ whose expression in normal unselected $\mathrm{T}$ cells is only $\approx 1.5 \%(31,32)$. Unlike the other lupus patients, none of the Th lines from this patient used the V $\alpha 8$ gene family. Finally, Th lines MD30 and MD28 used identical TCR $\alpha$ chains but they had different TCR $\beta$ chains.

Fig. 3 shows TCR sequences of lupus Th lines from patient DS-2. Again, charged residues are prominent in the CDR3 loops of these autoimmune TCRs. The Th clone DD2 has a highly charged TCR $\beta$ chain junctional region. As will be shown below, this clone responds to nucleosomes. The Th line DD30 


\begin{tabular}{|c|c|c|c|c|c|c|c|c|c|}
\hline $\mathbf{T}_{\mathbf{B}}$ Line & $\mathbf{V} \boldsymbol{\beta}$ & Junction & $\mathbf{J} \boldsymbol{\beta}$ & $\begin{array}{l}V \beta / J \beta \\
\text { genes }\end{array}$ & $\mathbf{v} \alpha$ & Junction & $\begin{array}{l}V \alpha / J \alpha \\
\text { genes }\end{array}$ & $\underset{\alpha-\text { dsDNA }}{\text { Fold In }}$ & $\frac{\text { crease }^{*}}{\alpha-\text { ssDNA }}$ \\
\hline \multicolumn{10}{|c|}{ Patient YCY: } \\
\hline MD30 & CS & VPMTGN & GYTFGS & $4.1 / 1.2$ & $\mathbf{C A}$ & RETGRALTFGSG & $15.1 / A B 19$ & 3.9 & - \\
\hline MC19 & CA & $C_{k}$ & NTIAFFGQ & $20.1 / 1.1$ & CAA & LFQGAQRLVFGQG & $15.1 / 13$ & 4.1 & 2.7 \\
\hline \multirow[t]{2}{*}{ MC14 } & CAsS & PGG & SY:QYFGP & $8.1 / 2.7$ & CAAS & VVFGN/LTFGTG & $21.1 a / 25$ & 5.3 & - \\
\hline & & & & & CAV & FRNNIMRGAG & $w 27 / 39$ & & \\
\hline MD32 & CASS & $\mathbf{L}$ & Q TQYFGP & $5.1 / 2.5$ & c & IVRPRE & $4.3 / 30$ & 82.9 & - \\
\hline \multirow[t]{2}{*}{ MC13 } & CAsS & $\mathbf{L}$ & QWTQYFGP & $5.1 / 2.5$ & C & ILCYNNNIRFGAG & $4.1 / 39$ & 14.6 & 7.1 \\
\hline & CSA & RTSGA & QWTQYFGP & $2.1 / 2.5$ & & & & & \\
\hline MD31 & CASS & IAGAI & NTALFGQ & $17.1 / 1.1$ & CAV & GGSNYQLIWGAG & $13.1 / 41$ & 7.1 & - \\
\hline MC36 & CAss & QGQGA & GLFFGE & $9.1 / 2.2$ & CAAS & RLAGNMLTFGGG & $21.1 a / 28$ & 4.1 & - \\
\hline MD28 & CAWS & LLGGGVL & TQYFGP & $20.1 / 2.5$ & $C A$ & R"TGRRALTFGSG & $15.1 / A B 19$ & 11.9 & - \\
\hline
\end{tabular}

Figure 2. Amino acid sequences of TCR $\alpha$ and $\beta$ chains expressed by potentially pathogenic, autoantibody-inducing Th lines from lupus patient MCM. The V $\alpha 15.1$ sequences of Th lines MD28 and MD30 matched those of HAVT31 in reference 18, whereas V $\alpha 15.1$ sequence of MC19 matched AC24 sequence reported in reference 23. The V $\alpha$ w27 of Th line MC14 matched in sequence with IGRa05 in reference 24 . The V $\alpha 4$ sequence of Th line MD32 was identical to $\mathrm{V} \alpha 4.3$ sequence reported in reference 18, except that the former had 3 residues (A,T,L) of $\mathrm{V} \alpha$ 4.1/ 4.2 at positions 80-82 instead of the corresponding residues $(\mathrm{R}, \mathrm{Y}, \mathrm{V})$ of $\mathrm{V} \alpha$ 4.3. The $\mathrm{J} \alpha$ sequences of Th lines MD28 and MD30 are identical to the $\mathrm{J} \alpha \mathrm{AB} 19$ sequence in reference 23.

was CD4-/CD8- or double negative (DN) in phenotype (11). Remarkably, like the Th lines from JCA, these Th clones also predominantly used a $\mathrm{V} \alpha 8$ gene ( 3 out of 3 lines).

Fig. 4 shows TCR sequences of autoimmune Th lines from lupus patient SE-2. As in the previous patients, these Th lines also have prominent charged motifs in their TCR CDR3, although they are heterogeneous in sequence. Approximately $42 \%$ ( 5 out of 12) of the Th lines used $\mathrm{J} \beta 1.1$ gene whose normal usage frequency is $5-15 \%$ (31). Th clones SC2 and SC3 have identical TCR sequences, whereas clones SC24 and SC31 have identical TCR $\beta$ but different TCR $\alpha$ chains. Th line SD21 is biclonal because out of 10 cDNA PCR products sequenced 3 had the first and 7 had the second TCR $\beta$ chain sequence.
Again, 36\% (4 out of 11) of the Th lines used a V $\alpha 8$ gene. Moreover, the following pairs of Th clones shared identical TCR $\alpha$ chains but they had distinct TCR $\beta$ chains: SC31 and SC32; SC33 and SC34; and SC24 and SC30.

Fig. 5 shows the TCR sequences of autoantibody-inducing Th lines from the fifth lupus patient, HS-2. Charged residues are prominent again in these TCR CDR3 loops. As shown below, Th clones HD56, HD40, HD47, and HD51 from this patient are specific for the nonhistone chromosomal protein HMG. The Th line HD47 is biclonal with two TCR $\beta$ chains. Like the three other lupus patients, a high proportion, $50 \%$ (4 out of 8 ), of the Th lines from this patient uses a V $\alpha 8$ gene.

However, $\mathrm{V} \alpha 8$ gene expression in the total peripheral blood

\begin{tabular}{|c|c|c|c|c|c|c|c|c|c|}
\hline $\mathbf{T}_{\mathrm{B}}$ Line & $\mathbf{V} \boldsymbol{\beta}$ & Junction & $\mathbf{J} \boldsymbol{\beta}$ & $\begin{array}{l}V \beta / J \beta \\
\text { genes }\end{array}$ & $\mathbf{V} \boldsymbol{\alpha}$ & Junction & $\begin{array}{l}V \alpha / J \alpha \\
\text { genes }\end{array}$ & $\underset{\alpha \text {-dsDNA }}{\text { Fold In }}$ & $\frac{\text { crease }^{*}}{\alpha-\text { ssDNA }}$ \\
\hline \multicolumn{10}{|c|}{ Patient DS-2: } \\
\hline $\mathrm{DD} 30$ (DN) & CASSL & LRI & NSPLAFGN & $6.9 / 1.6$ & CAA & GGYSTLTFGRG & $8.1 / 31$ & 3.6 & 8.2 \\
\hline DD22 & CASS & FGPG & Y & $3.3 / 2.7$ & & n.d. & & 2.3 & 5.8 \\
\hline \multirow[t]{2}{*}{ DD18 } & CASSL & ARVGGN & T:SQYFGP & $6.2 / 2.3$ & CAA & AWSQGAQKLVFGQG & $8.1 / 13$ & 2.5 & 7.1 \\
\hline & & & & & CAVs & KRTSGSRLTFGEG & $29.1 / 35$ & & \\
\hline DD2 & CSA & RaRGY & NQPQAFGD & $2.1 / 1.5$ & CAAS & LAGANSKLTFGKG & $8.1 / 207$ & 5.1 & 7.3 \\
\hline
\end{tabular}

Figure 3. TCR $\alpha$ and $\beta$ chain junctional region sequences of autoimmune Th lines from lupus patient DS-2. The Th line DD2 has a J $\alpha$ sequence identical to IGRJa07 in reference 24 . 


\begin{tabular}{|c|c|c|c|c|c|c|c|c|c|}
\hline $\mathbf{T}_{\mathbf{H}}$ Line & $\mathbf{V} \boldsymbol{\beta}$ & Junction & J $\beta$ & $\begin{array}{l}V \beta / J \beta \\
\text { genes }\end{array}$ & $\mathbf{V} \boldsymbol{\alpha}$ & Junction J $\alpha$ & $\begin{array}{l}V \alpha / J \alpha \\
\text { genes }\end{array}$ & $\underset{\alpha \text {-dsDNA }}{\text { Fold In }}$ & $\frac{\text { crease }^{\star}}{\alpha-\text { ssDNA }}$ \\
\hline \multicolumn{10}{|c|}{ Patient SE-2: } \\
\hline \multirow[t]{2}{*}{ SD21 } & CATS & Gep & Y:QYFGP & $15.1 / 2.7$ & CAV & IGRGSQGNLIFGKG & $2.1 / a 06$ & 14.6 & - \\
\hline & CASS & ERTGG & Q TRYFGP & $9.1 / 2.5$ & & & & & \\
\hline $\operatorname{sc} 33$ & CAS & RAYR:G & TAFFGQ & $13 / 1.1$ & CAAS & IIPGNQFYFGTG & $8.1 / 21$ & 17.0 & - \\
\hline $\operatorname{sc24}$ & CASS & MSGL & NTIAFFG & $17.1 / 1.1$ & CAV & WLGGSNYLLTFGKG & $29.1 / 11$ & 14.6 & - \\
\hline SC31 & CASS & MSGL & NTIA AFFG & $17.1 / 1.1$ & $\mathbf{C A}$ & WSWYQLIWGAG & $8.2 / 41$ & 23.9 & - \\
\hline $\operatorname{sc2}$ & cAss & LTR & NTIAFFGQ & $8.1 / 1.1$ & CAAS & AGITRGAAYQLIWGAG & $21.1 a / 41$ & 44.7 & - \\
\hline $\operatorname{sc3}$ & CAss & LTR & NTIAFFGQ & $8.1 / 1.1$ & CAAS & AGITRGAAYQLIWGAG & $21.1 a / 41$ & 17.0 & 1.4 \\
\hline sc34 & cs & VRLG & TQYFGP & $2.1 / 2.3$ & CAAS & IFPGNQFYFGTG & $8.1 / 21$ & 17.8 & - \\
\hline SD15 (DN) & CAss & SGVAGGR & QYFGP & $5.1 / 2.7$ & crvs & AFRGSTLGRLYFGRG & $w 24 / 17$ & 11.1 & 1.6 \\
\hline \multirow[t]{2}{*}{ SC28 } & CAss & MRGANR: & SPLAFGN & $12.4 / 1.6$ & cvvs & RSTLTFGKG & $1.2 / 31$ & 21.0 & 4.6 \\
\hline & & & & & CA & FYYGSSNTGKLIFGQG & $2.2 / 7$ & & \\
\hline $\operatorname{sc30}$ & CAIS & GWTGG & SPLAFGN & $12.2 / 1.6$ & CAV & BLSGGSNYRLTFGKG & $29.1 / 11$ & 4.1 & 3.2 \\
\hline SD19 & CASS & PSA & SGNTIYFGE & $6.9 / 1.3$ & & n.d. & & 9.6 & 1.4 \\
\hline sc32 & CAS & IGSWGG & NYGYTFGS & $5.5 / 1.2$ & $C A$ & RSWYLIWGAG & $8.2 / 41$ & 19.9 & - \\
\hline
\end{tabular}

Figure 4. TCR $\alpha$ and $\beta$ chain sequences of autoantibody-inducing Th lines from lupus patient SE-2. Th line SD15 has a V $\alpha$ (V $\alpha$ w24) sequence identical to IGRa02 in reference 24, and SD21 has a J $\alpha$ sequence matching IGRJa06 in reference 24.

T cells of lupus patients was equivalent to that in normal subjects (data not shown) when TCR cDNA from the total, unselected $\mathrm{T}$ cells was amplified using different $5^{\prime} \mathrm{V} \alpha$ gene family primers and 3' $\mathrm{C} \alpha$ primer as described (33).
Antigenic specificities of potentially pathogenic anti-DNA autoantibody-inducing $T$ helper clones. 6-8 wk after initiating the limiting dilution cultures from lupus patients, the Th lines were selected for their ability to induce the production of poten-

\begin{tabular}{|c|c|c|c|c|c|c|c|c|c|}
\hline$T_{B}$ Line & $\mathbf{v} \boldsymbol{\beta}$ & Junction & $\mathbf{J} \beta$ & $\begin{array}{l}V \beta / J \beta \\
\text { genes }\end{array}$ & $\mathbf{v} \boldsymbol{\alpha}$ & Junction & $\begin{array}{l}V \alpha / J \alpha \\
\text { genes }\end{array}$ & $\underset{\alpha \text {-dsDNA }}{\text { Fold In }}$ & $\frac{\text { crease }^{\star}}{\alpha-\text { ssDNA }}$ \\
\hline \multicolumn{10}{|c|}{ Patient HS-2: } \\
\hline HD53 & CAsS & PGG & SYQYFGP & $8.1 / 2.7$ & CAA & R.GFNRFYFGSG & $8.1 / 29$ & 4.6 & 5.6 \\
\hline HD54 & CATS & LA & SY QYFGP & $12.6 / 2.7$ & CAAS & KGNTGGFKTIFGAG & $8.1 / 42$ & 7.7 & 1.4 \\
\hline HD47 & $\begin{array}{l}\text { CASSL } \\
\text { CS }\end{array}$ & $\begin{array}{l}\text { LGGR } \\
\text { SSERERT }\end{array}$ & $\begin{array}{r}\text { TY TQYFGP } \\
\text { QFFGP }\end{array}$ & $\begin{array}{l}6.2 / 2.3 \\
2.1 / 2.1\end{array}$ & CAV & VNQAGTALIFGKG & $13.1 / 19$ & 2.7 & - \\
\hline HD59 & CASSL & ARVGGN & TWTQYFGP & $6.2 / 2.3$ & $\begin{array}{l}\text { CAAS } \\
\text { CAAS }\end{array}$ & $\begin{array}{r}\text { MFGN } \\
\text { TGNITFGTG }\end{array}$ & $\begin{array}{l}8.1 / 25 \\
8.1 / 39\end{array}$ & 7.7 & 6.4 \\
\hline HD56 & CASS & AGA & NTIYFG & $13.1 / 1.3$ & CAV & TKTGANNLFFGTG & $29.1 / 36$ & 3.6 & - \\
\hline HD4O & CASS & LAPEPT & YGYTFGS & $5.1 / 1.2$ & CAV & NI=SSNYLIWGAG & $2.1 / 41$ & 2.7 & - \\
\hline HD51 & CASS & RRAFN & GYTFGS & $6.9 / 1.2$ & $\begin{array}{l}\text { CAA } \\
\text { CA }\end{array}$ & $\begin{array}{l}\text { NPKGSARQLTFGSG } \\
\text { LRYESSYKLIFGSG }\end{array}$ & $\begin{array}{l}8.1 / 3 \\
2.1 / 2\end{array}$ & 6.4 & 7.1 \\
\hline HD22 & CASSL & WQF & YNSPLAFGN & $6.6 / 1.6$ & CAA & ALIFQGGS & $21.1 a / 30$ & 1.8 & - \\
\hline
\end{tabular}

Figure 5. TCR $\alpha$ and $\beta$ chain sequences of autoimmune Th lines from lupus patient HS-2. 
tially pathogenic anti-DNA autoantibodies in vitro when cocultured with autologous B cells $(1,11)$. No exogenous antigens or autoantigen preparations were deliberately added to the Th cell line cultures for their maintenance, therefore they had to be frozen quickly. RNA was extracted from these Th lines for TCR gene analysis and the Th lines were stored frozen for subsequent studies. As is the case with human $\mathrm{T}$ cell clones, particularly those that have not been grown and selected by deliberately adding some antigen in culture, these Th clones were difficult to regrow. Even then, 10 of the $40 \mathrm{CD} 4+\mathrm{Th}$ lines could be revived in culture for further functional studies and all 10 responded to anti-CD3 stimulation. Since the CDR loops of the TCRs expressed by these Th clones had many charged residues, we tested them for any response against certain candidate autoantigens of lupus that have long runs of charged residues $(29,34)$.

Since these Th lines were autoreactive, i.e., they had proliferated spontaneously to some endogenous antigen presented on MHC class II molecules by autologous EBV-BCL as APC (11), the choice of appropriate APC for these antigen presentation studies was crucial. Subclones of autologous EBV-BCL were derived that did not stimulate the Th lines by themselves as strongly as the original EBV-BCL lines (11) and these were used as APC in most cases. In addition, Boleth, an EBV-BCL derived from a normal subject that was HLA-DR matched with the restricting element for the Th lines from patient HS-2 was also used as APC in those cases (Table II). 7 of the 10 antiDNA autoantibody-inducing Th lines responded to one of the autoantigens tested, as shown in Table II and described in the text. Four of the potentially pathogenic, autoantibody-inducing Th lines responded to HMG and/or HMG/DNA complex and the intensity of response to this autoantigen was similar to their response to anti-CD3. All four Th lines were derived from lupus patient HS-2, but they express different TCR $\alpha$ and $\beta$ chains that nevertheless have prominent charged motifs (Fig. 5). All four Th lines were HLA-DR restricted. Interestingly, three of these Th lines could respond to HMG/DNA complex but not to HMG alone (Table II). None of the Th lines responded to DNA alone or to the recombinant HMG-1 or HMG-17 proteins. The HMG-specific Th lines did not respond to the other autoantigens tested, such as nucleosomes (Table II), as well as histones, DNA, HSP, snRNP, or heparan sulfate proteoglycans (data not shown). The mean SI \pm SD of the Th lines for these latter antigens were as follows: Th line HD56, 0.99 \pm 0.05 ; line HD40, 1.00 \pm 0.04 ; line HD47, 0.95 \pm 0.05 ; and line HD51, $1.01 \pm 0.07$

2 of the 10 autoantibody-inducing Th lines responded to nucleosomes but not to the other autoantigens (Table II). These Th lines were again DR-restricted and their level of response to the autoantigen was similar to their anti-CD3 response. One of the Th line DD-2, derived from lupus patient DS-2, also responded to histone $\mathrm{H}-4$, but not to the other histone components of the nucleosome (Fig. 6), whereas Th line MD31 derived from patient MCM could respond when presented with the whole nucleosome particle (Table II), but not when its component histones were fed to the APC (data not shown). Again the mean SI \pm SD of these Th lines to the other autoantigens in the panel that are not shown in Table II were as follows: DD-2, $1.01 \pm 0.1$, and MD31, 0.95 \pm 0.1 .

Finally, 1 of the 10 autoantibody-inducing Th lines, SC31 that was derived from lupus patient SE-2 (Fig. 4, but not shown in Table II), responded consistently to pure dsDNA $(10 \mu \mathrm{g} / \mathrm{ml})$ in 5 separate experiments with a mean $\mathrm{SI} \pm \mathrm{SD}$ of $5.1 \pm 1.1$, but its response to nucleosomes was variable with SI ranging between 1.0 and 3.4 (mean 1.8 \pm 0.8 ). This Th line did not respond to the other autoantigens, such as HMG, HMG/DNA, snRNP, HSP, or heparan sulfate (mean SI $=0.98 \pm 0.14$ ).

\section{Discussion}

Although the primary autoantigen responsible for driving the pathogenic autoimmune response in SLE is unknown, we were successful in cloning the IgG anti-DNA autoantibody-inducing Th cells that are selectively increased in patients with active lupus nephritis and are functionally relevant to the disease (1, 11). We found that not all autoreactive $T$ cells could induce the potentially pathogenic autoantibodies. Among 396 autoreactive $\mathrm{T}$ cell lines derived from 5 patients with active lupus nephritis, only $59(15 \%)$ had the ability to selectively augment the production of the pathogenic variety of anti-DNA autoantibodies that are IgG in class, cationic in charge, specific for dsDNA, and clonally restricted in isoelectric focusing spectrotype $(1,11)$. Therefore, autoantibody-inducing help for the potentially pathogenic population of autoimmune B cells in lupus is provided by special autoimmune Th cells that arise spontaneously in patients with active lupus nephritis $(1,11)$.

Analysis of the TCR repertoire of these potentially pathogenic Th cells of lupus provides important clues regarding their antigenic specificities. Before undertaking such an analysis, we realized that human lupus is a complex disease with many layers of events occurring during the development of nephritis (35). The initial population of pathogenic Th cells could become diluted as other autoimmune $\mathrm{T}$ cells are recruited with progression of disease. Moreover, each lupus patient had a different HLA haplotype. Despite those complexities, the CD4+ Th clones, which are probably the prime movers in the pathogenic autoimmune response (11), recurrently displayed motifs of charged residues in their TCR-CDR3 loops similar to our results in murine models of lupus $(14,15)$. Indeed, the target antigens for the autoantibodies of SLE have not only cationic residues but some have long runs of anionic or mixed charge residues (34). These target autoantigens of lupus B cells may also contain the epitopes for these pathogenic autoantibody-inducing $\mathrm{Th}$ clones, since an interaction between reciprocally charged residues in the TCR-CDR3 loop and their corresponding antigenic peptide has been found in several antigenic systems $(14,15$, $29,36-38)$. Besides the charged amino acids highlighted in Figs. 1-5, these autoimmune TCR-CDR3 loops also contain tyrosine, tryptophan, and phenylalanine, whose electron-rich aromatic rings could interact with positively charged residues in the autoantigen(s) (37). Conversely, glutamine and asparagine which are also present in those CDR3 loops could interact with negatively charged residues in the autoantigen (37). Of course, other $\mathrm{T}$ cells in the lupus patients that are incapable of inducing anti-DNA autoantibodies could also possess charged residues in their TCR since those T cells could be specific for charged peptides derived from exogenous antigens $(37,38)$. The charged motif in the CDR3 of the TCRs simply offers a clue regarding the nature of the autoantigens that might prime these autoimmune Th cells of lupus.

The heterogeneity in their junctional sequences indicate that these TCRs are specific for diverse autoantigenic epitopes, however, different TCRs can also recognize a single peptide-MHC complex configuration in different ways (37-39). Indeed, in 
Table II. Antigenic Specificities of Pathogenic Anti-DNA Autoantibody-inducing Th Cell Lines

\begin{tabular}{|c|c|c|c|c|c|c|}
\hline \multirow{2}{*}{$\begin{array}{l}\text { Lupus } \\
\text { Th line }\end{array}$} & \multirow{2}{*}{$\begin{array}{l}\text { HLA } \\
\text { restriction }^{\ddagger}\end{array}$} & \multicolumn{5}{|c|}{ Proliferative response* of Th cells cultured with: } \\
\hline & & $\mathrm{APC}^{8}$ & APC plus anti-CD3 & APC plus HMG & APC plus HMG/DNA & APC plus nucleosomes \\
\hline & & \multicolumn{5}{|c|}{ Mean cpm $\pm S E M(S I)$} \\
\hline HD56 & DR & $755 \pm 80$ & $\begin{array}{c}8,110 \pm 295 \\
(10.7)\end{array}$ & $\begin{array}{c}\text { 8,339 } \pm 821 \\
(\mathbf{1 1 . 1})\end{array}$ & $\begin{array}{c}7,216 \pm 426 \\
(9.6)\end{array}$ & $\begin{array}{c}784 \pm 60 \\
(1.0)\end{array}$ \\
\hline HD40 & DR & $1,360 \pm 72$ & $\begin{array}{c}9,830 \pm 590 \\
(7.2)\end{array}$ & $\begin{array}{c}2,105 \pm 404 \\
(1.5)\end{array}$ & $\begin{array}{c}\mathbf{9 , 8 6 2} \pm 330 \\
\quad(\mathbf{7 . 3})\end{array}$ & $\begin{array}{c}2,072 \pm 134 \\
(1.5)\end{array}$ \\
\hline HD47 & DR & $1,496 \pm 32$ & $\begin{array}{c}10,043 \pm 423 \\
(6.7)\end{array}$ & $\begin{array}{c}2,374 \pm 176 \\
(1.6)\end{array}$ & $\begin{array}{c}\mathbf{8 , 1 0 2} \pm 169 \\
(5.4)\end{array}$ & $\begin{array}{c}2,353 \pm 134 \\
(1.6)\end{array}$ \\
\hline HD51 & DR & $2,851 \pm 165$ & $\begin{array}{c}17,995 \pm 1,551 \\
(6.3)\end{array}$ & $\begin{array}{c}4,182 \pm 510 \\
(1.5)\end{array}$ & $\begin{array}{c}17,427 \pm 921 \\
(6.1)\end{array}$ & $\begin{array}{c}3,557 \pm 467 \\
(1.3)\end{array}$ \\
\hline DD2 & DR & $868 \pm 58$ & $\begin{array}{c}14,617 \pm 916 \\
(16.8)\end{array}$ & $\begin{array}{c}913 \pm 99 \\
(1.1)\end{array}$ & $\begin{array}{c}1,191 \pm 106 \\
(1.3)\end{array}$ & $\begin{array}{c}\mathbf{9 , 0 3 3} \pm 404 \\
(\mathbf{1 0 . 4})\end{array}$ \\
\hline MD31 & DR & $1,724 \pm 49$ & $\begin{array}{c}10,625 \pm 237 \\
(6.2)\end{array}$ & $\begin{array}{c}2,954 \pm 122 \\
\quad(1.7)\end{array}$ & $\begin{array}{l}2,226 \pm 110 \\
(1.3)\end{array}$ & $\begin{array}{c}8,913 \pm 182 \\
(5.2)\end{array}$ \\
\hline
\end{tabular}

* The proliferative response patterns were reproduced 5-10 times with each Th cell line. SI in response to the nucleoprotein antigen that specifically stimulated a particular Th line were always $>3$ SD over the background responses to the nonstimulating antigens. Optimal results are shown, where background stimulation of the Th cells with APC alone presenting nuclear antigens of endogenous origin was low. Significant proliferation and SI in response to the added antigen(s) are shown in bold. All antigens were used at a concentration of $10 \mu \mathrm{g} / \mathrm{ml}$ to pulse the APC. ${ }^{\ddagger} \mathrm{HLA}$ restriction was determined by blocking of antigen-specific proliferation of the Th clones using a panel of anti-class II mAbs. The anti-DR mAb inhibited proliferation of the Th clones to their respective antigens by $75-95 \%$ whereas the anti-DP and anti-DQ mAbs inhibited by only $5-15 \%$ (see Fig. 6). ${ }^{\S}$ Since nuclear antigens from dying cells in the cultures could be presented by the APC even without the addition of such antigens, the background stimulation (T \pm APC alone) was kept low by loading the APC that are shown in this column only with a control irrelevant antigen like tetanus toxoid (Sigma Chemical Co., $10 \mu \mathrm{g} / \mathrm{ml}$ ) to compete with spontaneous autoantigen-processing by the APC. Furthermore, in the case of each Th clone, the nuclear antigens that did not stimulate significantly might have also acted as such competitors.

the murine models of lupus nephritis we find the same heterogeneity in the TCR sequences of pathogenic Th clones that are specific for nucleosomes $(14,15,29)$. In addition to CDR3, other regions of the TCR molecule, particularly CDR1 and CDR2 may also contact the antigenic determinants $(40,41)$. Indeed, charged residues were also prominent in these other antigen-binding regions of the lupus TCRs that were found here to be specific for HMG and histone proteins (Fig. 7).

Although the TCR gene usage was heterogeneous in this spontaneous and systemic autoimmune disease, there were some

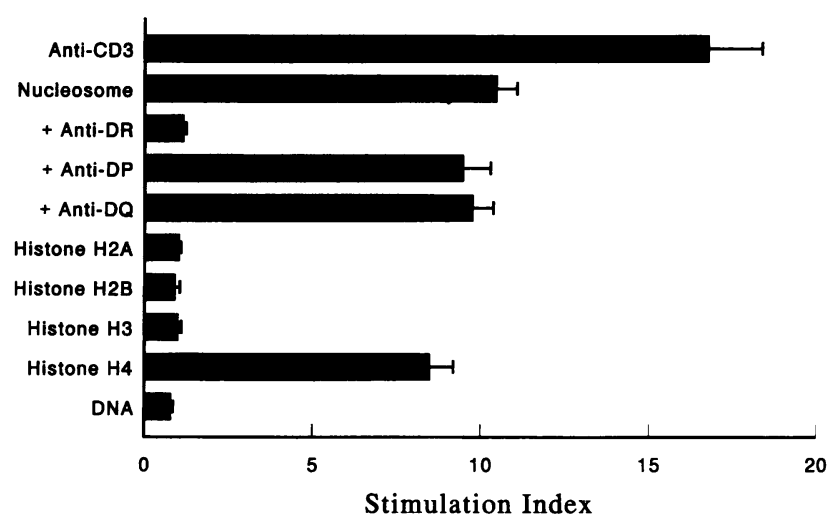

Figure 6. Proliferative response (stimulation index) of potentially pathogenic anti-DNA autoantibody-inducing Th line DD2 to mononucleosomes and its components presented by autologous EBV-BCL APC. The effects of anti-MHC class II mAbs on nucleosomal antigen-specific proliferation of DD2 are also shown. notable recurrences besides the charged motifs. In four of the five patients, the frequency of $\mathrm{V} \alpha 8$ gene usage was markedly increased among their pathogenic autoantibody-inducing $\mathrm{Th}$ lines ranging from 36 to $100 \%$, in contrast to normal peripheral blood $\mathrm{T}$ cells where its expression is only $\approx 9 \%(31,32)$. The frequency of $\mathrm{V} \alpha 8$ gene usage was not increased in the total $T$ cell population of lupus patients but only in these select autoimmune Th cells from four out of the five patients. Interestingly, human $\mathrm{T}$ cell lines selected for reactivity against another charged autoantigen, myelin basic protein, also use $\mathrm{V} \alpha 8$ genes predominantly (42). Secondly, although not a major feature, several sets of independently derived Th clones from each lupus patient here had identical TCR $\alpha$ or TCR $\beta$ or both TCRs, such as: Th clones, SC24/SC30, SC33/SC34, SC31/SC32, SC24/ SC31, and SC2/SC3 from patient SE-2 (Fig. 4); MD30/MD28 from patient MCM (Fig. 2); and JC2/JC3 from patient JCA (Fig. 1). This feature could again be due to selection of these Th cells by certain autoantigens comparable with other welldefined antigenic systems $(37,38)$.

To understand the mechanism of the pathogenic anti-DNA autoantibody response in lupus, it is crucial to determine which autoantigens these autoantibody-inducing Th cells see. Based on the finding of charged residues in their TCRs, we tested the response of the anti-DNA autoantibody-inducing Th lines with certain candidate autoantigens that have charged residues (34). These autoantigens are recurrently found to be the targets of autoantibodies in lupus and are associated with anti-DNA autoantibody production. We also took into account that these Th lines of lupus preferentially help the select population of B cells that produce potentially pathogenic anti-DNA autoantibodies $(1,11)$. Hence, those autoimmune $B$ cells probably in turn pres- 

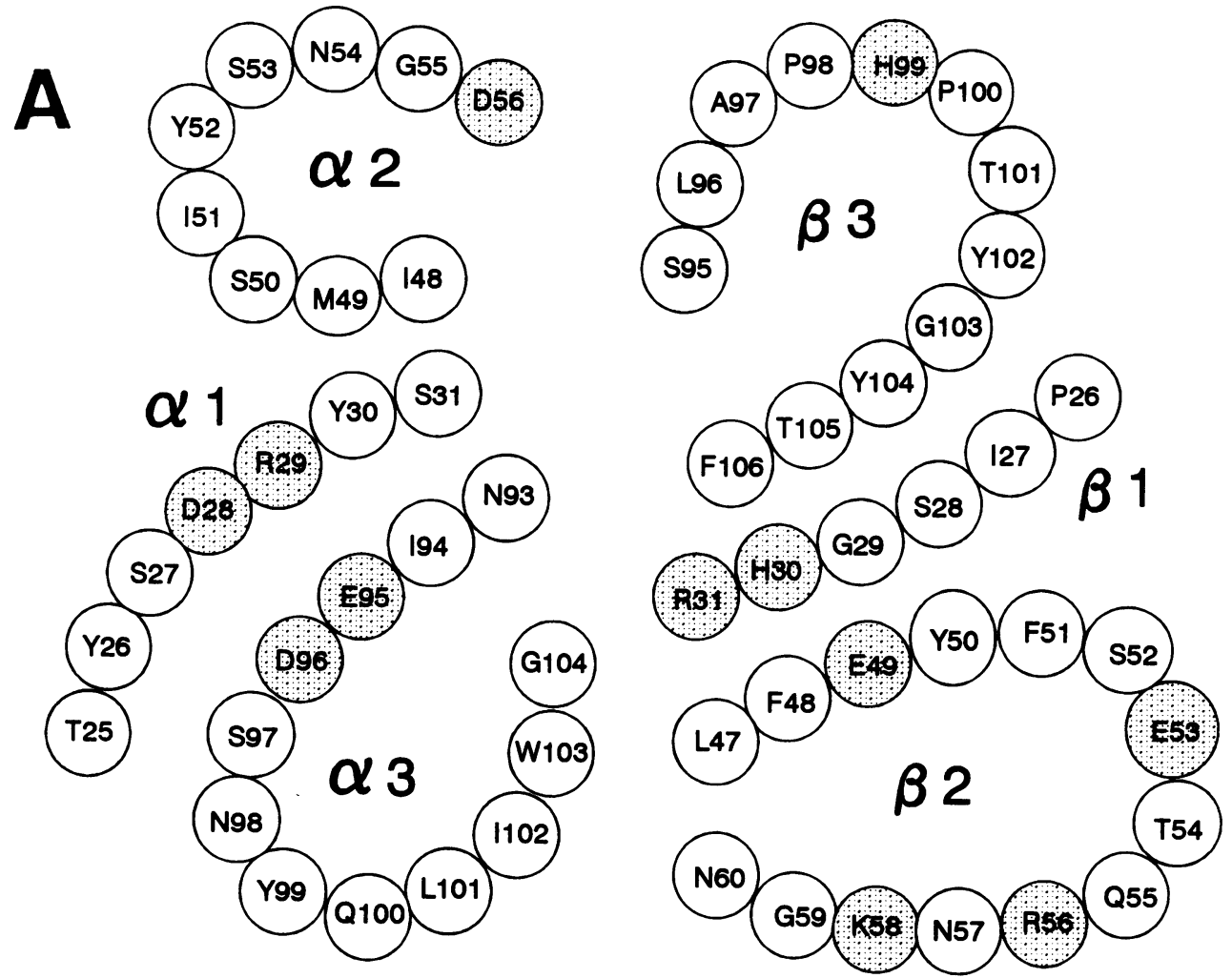

\section{HD40-TCR}
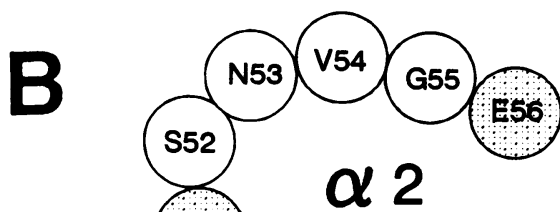

(R51:
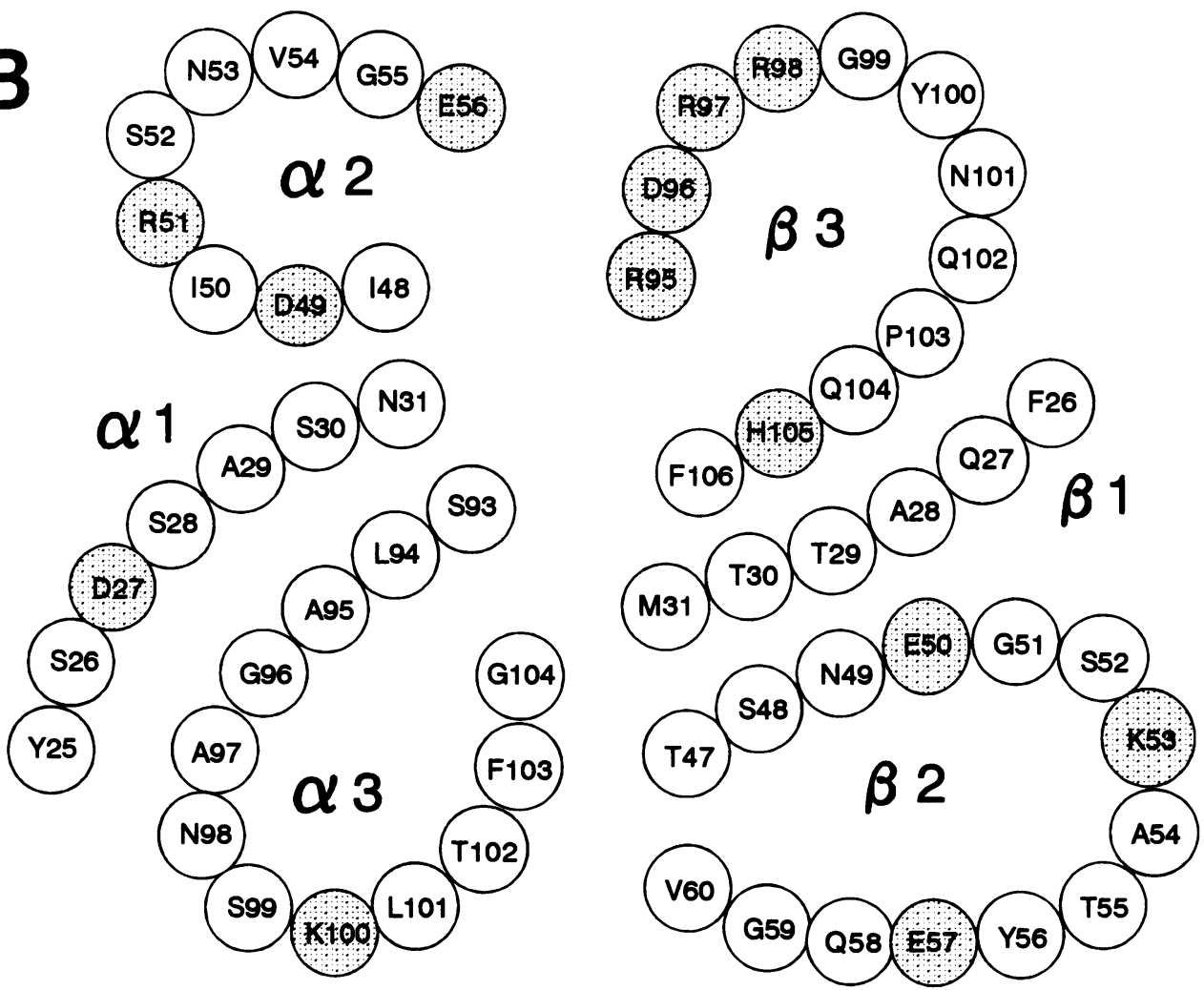

\section{DD2-TCR}

Figure 7. Schematic diagram of TCR $\alpha / \beta$ chain residues that would form antigen/MHC-binding loops according to models in references 40 and 41 . TCR $(\mathrm{V} \alpha 2.1 / \mathrm{J} \alpha 41, \mathrm{~V} \beta 5.1 / \mathrm{J} \beta 1.2)$ of anti-DNA autoantibody-inducing Th line HD40 that is specific for HMG/DNA $(A)$ and TCR (V $\alpha 8.1 /$ $\mathrm{J} \alpha \mathrm{a} 07, \mathrm{~V} \beta 2.1 / \mathrm{J} \beta 1.5)$ of Th line DD2 that is specific for the core histone $\mathrm{H} 4$ in nucleosomes $(B)$ are shown. Single letter amino acid codes with position number of the residues are shown; charged residues are highlighted. CDR 1, 2, and 3 extend from positions $25-$ $31,48-56$, and 93-104, respectively for TCR $\alpha$, and from positions $26-31,47-60$, and $95-106$, respectively for TCR $\beta$ chains. 
ent some autoantigen to these Th cells to perpetuate the pathogenic autoimmune response $(14,43-46)$. Therefore, we selected those charged autoantigens for testing that could be efficiently picked up by such anti-DNA B cells for processing, such as different nucleoproteins that complex with DNA (HMG, histones), or HSPs that interact with DNA-binding proteins/transcription factors, or ribonucleoproteins and heparan sulfate proteoglycans that are cross-reactive antigens for anti-DNA autoantibodies $(29,47-49)$.

Among 10 anti-DNA autoantibody-inducing Th clones that could be revived for these antigenic specificity studies, 4 responded to the nonhistone chromosomal protein HMG. The HMG proteins are highly charged with runs of negative and positive residues; they associate with DNA in transcriptionally active chromatin (50). Like anti-dsDNA antibodies, autoantibodies to HMG are frequently found in sera of lupus patients with active disease (27). But this study does not involve antiHMG or antihistone antibodies $(27,51)$. The remarkable result here is that HMG-reactive T cells help the production of potentially pathogenic anti-DNA autoantibodies in lupus. Anti-HMG antibodies could be an epiphenomena in the pathogenesis of lupus nephritis, since the HMG-specific Th cells would help in the production of both the anti-HMG and the pathogenic variety of anti-DNA autoantibodies. The anti-DNA B cells, which these Th cells specifically help, probably take up DNA-bound HMG and present to these Th cells. Thus the Th cell and B cell epitopes are on different molecules within the same chromatin particle allowing for cognate interaction between the two types of cells $(29,52,53)$. Interestingly, three of the four Th clones responded to HMG only when it was presented as a complex with DNA. Possibly, the peptide epitopes in HMG that are critical for the Th cells were protected by DNA during processing or these Th clones could recognize processed nucleotides (from the DNA) complexed with peptides (from the HMG), like arsenate- or fluorescein-specific T cells that recognize haptens or haptenated peptides $(41,54)$. Indeed, nucleotidespecific $\gamma / \delta \mathrm{T}$ cells have been recently described (55). Other Th cells in the panel responded to nucleosomal antigens which are highly charged histones complexed with DNA. One of the Th clones, DD2, actually responded to the arginine-rich histone $\mathrm{H} 4$ which is part of the mononucleosome core, whereas the other, MD31, responded only when the whole particle was presented and not to its histone components. The latter feature is also observed in case of pathogenic anti-DNA autoantibodyinducing Th cells that respond to nucleosomes in murine SLE (29). Either nucleosomes as a whole are taken up more efficiently by anti-DNA antibody receptors on the pathogenic $B$ cells $(29,56)$ or by special nucleosome receptors found on all types of APC (57). Nucleosome-specific T cells play a major role in the development of lupus nephritis in murine models (29) and consequently production of autoantibodies to nucleosomes is associated with lupus nephritis $(29,58,59)$. It is not clear how autoimmunization against nucleosomes occurs in lupus. These autoantigens are released normally as a product of apoptosis $(60,61)$. But large amounts of nucleosomes are released in patients undergoing chronic hemodialysis without the development of lupus (62). Perhaps abnormal autoantigen processing and presentation could lead to the generation of nucleosome-specific $T$ cells in lupus. Clearly, the pathogenic antiDNA B cells could perform as abnormal APC $(14,29,46)$. Interestingly, one of the autoantibody-inducing Th lines in the panel, SC31, responded consistently to pure dsDNA with a mean SI that was $29 \mathrm{SD}$ above its SI response to the other autoantigens. However, SC31 responded poorly to nucleosomes suggesting that this Th line may be specific for nucleotides like some other $T$ cells (55). Although the purified dsDNA preparation (Sigma Chemical Co. catalogue no. D-4764, ultrapure DNA) was devoid of proteins, it could complex with some proteins in the culture and then be presented by the APC. These possibilities will be tested in another study.

Deliberate immunization of mice with various DNA-binding proteins of exogenous or endogenous origin along with CFA leads to the production of anti-DNA autoantibodies, particularly in lupus-prone genetic backgrounds (63-65). Even methylated BSA carrier-specific $T$ cells could help in the production of anti-DNA autoantibodies when $\mathrm{B} / \mathrm{W}$ lupus mice were immunized with methylated BSA-DNA complex (65). However, herein we have determined which of the naturally occurring and abundant autoantigens could trigger the spontaneously arising Th cells of lupus that preferentially induce potentially pathogenic anti-DNA autoantibodies. Our studies indicate that there is an underlying connection between the different autoantibodyproducing B cells of lupus $(35,66)$ as the diverse autoimmune B cells could share help from the same Th cells that are specific for endogenous chromosomal proteins that bind DNA. Thus a Th cell specific for HMG in chromatin could help different B cells producing either anti-HMG, or anti-DNA, or antinucleosome, or antihistone autoantibodies, because B cells specific for any of these autoantigenic components of chromatin could efficiently take up and process the entire chromatin particle and present the relevant HMG epitope from it to the Th cell. The same situation would apply to the nucleosome-specific Th cells of lupus (29). This interaction between the autoimmune $\mathrm{T}$ and B cells of human lupus is cognate, being HLA-DR restricted in the panel of Th cells we tested. A similar cognate interaction occurs in murine SLE and also in case of other autoantigenreactive $T$ cells in human lupus $(6,29,43,67-71)$. Defining the autoantigenic epitopes for these Th cells that drive the potentially pathogenic autoantibody-producing B cells would lead to an understanding of the etiologic mechanism of human lupus nephritis and specific intervention in the disease.

\section{Acknowledgments}

We thank Dr. Jo Verwilghen for advice regarding $\mathrm{T}$ cell line culture and maintenance.

This work was supported by National Institutes of Health grant AR39157 to S. K. Datta.

\section{References}

1. Shivakumar, S., G. C. Tsokos, and S. K. Datta. 1989. T cell receptor $\alpha / \beta$ expressing double negative (CD4-/CD8-) and CD4+ $\mathrm{T}$ helper cells in humans augment the production of pathogenic anti-DNA autoantibodies associated with lupus nephritis. J. Immunol. 143:103-112.

2. Suenaga, R., and N. I. Abdou. 1993. Cationic and high affinity serum IgG anti-dsDNA antibodies in active lupus nephritis. Clin. Exp. Immunol. 94:418422.

3. Suzuki, N., T. Harada, Y. Mizushima, and T. Sakane. 1993. Possible pathogenic role of cationic anti-DNA autoantibodies in the development of nephritis in patients with systemic lupus erythematosus. J. Immunol. 151:1128-1136.

4. Gauthier, V. J., and M. Mannik. 1990. A small proportion of cationic antibodies in immune complexes is sufficient to mediate their deposition in glomeruli. J. Immunol. 145:3348-3352.

5. Ebling, F., and B. H. Hahn. 1980. Restricted subpopulations of DNA antibodies in kidneys of mice with systemic lupus: comparison of antibodies in serum and renal eluates. Arthritis Rheum. 23:392-403.

6. Datta, S. K., H. Patel, and D. Berry. 1987. Induction of a cationic shift in 
IgG anti-DNA autoantibodies. Role of $\mathrm{T}$ helper cells with classical and novel phenotypes in three murine models of lupus nephritis. J. Exp. Med. 165:12521268.

7. Gavalchin, J., and S. K. Datta. 1987. The NZB x SWR model of lupus nephritis. II. Autoantibodies deposited in renal lesions show a restricted idiotypic diversity. J. Immunol. 138:138-148.

8. Datta, S. K., S. Rajagopalan, T. L. O'Keefe, S. Ghatak, and T. ImanishiKari. 1992. Pathogenic anti-DNA autoantibodies and pathogenic autoantibodyinducing T cells. In Molecular Immunobiology of Self-Reactivity. C. A. Bona and A. Kaushik, editors. Marcel Dekker, Inc., New York. 133-153.

9. Diamond, B., J. B. Katz, E. Paul, C. Aranow, D. Lustgarten, and M. D. Scharff. 1992. The role of somatic mutation in the pathogenic anti-DNA response. Annu. Rev. Immunol. 10:731-757.

10. Radic, M. Z., and M. Weigert. 1994. Genetic and structural evidence for antigen selection of anti-DNA antibodies. Annu. Rev. Immunol. 12:487-520.

11. Rajagopalan, S., T. Zordan, G. C. Tsokos, and S. K. Datta. 1990. Pathogenic anti-DNA autoantibody inducing $\mathrm{T}$ helper cell lines from patients with active lupus nephritis: isolation of CD4-/CD8- T helper cell lines that express the $\gamma / \delta$ T-cell receptor. Proc. Natl. Acad. Sci. USA. 87:7020-7024.

12. Rajagopalan, S., C. Mao, and S. K. Datta. 1992. Pathogenic anti-DNA autoantibody-inducing $\gamma / \delta \mathrm{T}$ helper cells from patients with lupus nephritis express unusual T cell receptors. Clin. Immunol. Immunopathol. 62:344-350.

13. Linker-Israeli, M., F. P. Quisimoro, and D. A. Horwitz. 1990. CD8+ lymphocytes from patients with systemic lupus erythematosus sustain, rather than suppress, spontaneous polyclonal IgG production and synergize with CD4+ cells to support autoantibody synthesis. Arthritis Rheum. 33:1216-1225.

14. Adams, S., P. Leblanc, and S. K. Datta. 1991. Junctional region sequences of T-cell receptor $\beta$ chain genes expressed by pathogenic anti-DNA autoantibodyinducing $\mathrm{T}$ helper cells from lupus mice: possible selection by cationic autoantigens. Proc. Natl. Acad. Sci. USA. 88:11271-11275.

15. Mao, C., G. E. Osman, S. Adams, and S. K. Datta. 1994. T cell receptor alpha-chain repertoire of pathogenic autoantibody-inducing $\mathrm{T}$ cells in lupus mice. J. Immunol. 152:1462-1470.

16. Martin, R., M. D. Howell, D. Jaraquemada, M. Flerlage, J. Reichert, S. Brostoff, E. O. Long, D. E. McFarlin, and H. F. McFarland. 1991. A myelin basic protein peptide is recognized by cytotoxic $\mathrm{T}$ cells in the context of four HLADR types associated with multiple sclerosis. J. Exp. Med. 173:19-24.

17. Broeren, C. P. M., G. M. G. M. Verjans, W. Van Eden, J. G. Kusters J. A. Lenstra, and T. Logtenberg. 1991. Conserved nucleotide sequences at the 5 ' end of $\mathrm{T}$ cell receptor variable genes facilitate polymerase chain reaction amplification. Eur. J. Immunol. 21:569-575.

18. Kimura, N., B. Toyonaga, Y. Yoshikai, R.-P. Du, and T. W. Mak. 1987. Sequences and repertoire of human T cell receptor $\alpha$ and $\beta$ chain variable region genes in thymocytes. Eur. J. Immunol. 17:375-383.

19. Ferradini, I., S. Roman-Roman, J. Azocar, H. Michalaki, F. Triebel, and T. Hercend. 1991. Studies on human T cell receptor $\alpha \beta$ variable region genes. II. Identification of four additional $\mathrm{V} \beta$ subfamilies. Eur. J. Immunol. 21:935942.

20. Uematsu, Y., H. Wege, A. Straus, M. Ott, W. Bannwarth, J. Lanchbury, G. Panayi, and M. Steinmetz. 1991. The T-cell receptor repertoire in the synovia fluid of a patient with rheumatoid arthritis is polyclonal. Proc. Natl. Acad. Sci. USA. 88:8534-8538.

21. Concannon, P., L. A. Pickering, P. Kung, and L. Hood. 1986. Diversity and structure of human T-cell receptor $\beta$-chain variable region genes. Proc. Natl. Acad. Sci. USA. 83:6598-6602.

22. Toyonaga, B., Y. Yoshikai, V. Vadasz, B. Chin, and T. W. Mak. 1985 Organization and sequences of the diversity, joining and constant region genes of the human T-cell receptor $\beta$ chain. Proc. Natl. Acad. Sci. USA. 82:8624-8628.

23. Klein, M. H., P. Concannon, M. Everett, L. D. H. Kim, T. Hunkapiller and L. Hood. 1987. Diversity and structure of human T-cell receptor $\alpha$-chain variable region genes. Proc. Natl. Acad. Sci. USA. 84:6884-6888.

24. Roman-Roman, S., L. Ferradini, J. Azocar, C. Genevee, T. Hercend, and F. Triebel. 1991. Studies on human T-cell receptor $\alpha / \beta$ variable region genes. Identification of seven additional $\mathrm{V} \alpha$ subfamilies and $14 \mathrm{~J} \alpha$ gene segments. Eur J. Immunol. 21:927-933.

25. Obata, F., M. Tsunoda, T. Kaneko, K. Ito, I. Ito, S. Masewicz, E. M. Mickelson, W. E. R. Ollier, G. Pawelec, M. Cella, G. B. Ferrara, and N. Kashiwagi. 1993. Human T-cell receptor TCRAV, TCRBV, and TCRAJ sequence newly found in T-cell clones reactive with allogeneic HLA class II antigens. Immunogenetics. 38:67-70.

26. Goodwin, G. H., A. Rabbani, R. H. Nicolas, and E. W. Johns. 1977. The isolation of the high mobility group non-histone chromosomal protein HMG 14 FEBS (Fed. Eur. Biochem. Soc.) Lett. 80:413-416.

27. Bustin, M., L. Einck, and J. Reisch. 1982. Autoantibodies to nucleosoma proteins: antibodies to HMG-17 in autoimmune diseases. Science (Wash. DC). 215:1245-1247.

28. Bianchi, M. E. 1991. Production of functional rat HMGl protein in Escherichia coli. Gene (Amst.). 104:271-275.

29. Mohan, C., S. Adams, V. Stanik, and S. K. Datta. 1993. Nucleosome: major immunogen for the pathogenic autoantibody-inducing T cells of lupus. $J$. Exp. Med. 177:1367-1381.

30. Malissen, M., J. Trucy, E. Jouvin-Marche, P.-A. Cazenave, R. Scollay, and B. Malissen. 1992. Regulation of TCR $\alpha$ and $\beta$ gene allelic exclusion during T-cell development. Immunol. Today. 13:315-322.

31. Moss, P. A. H., W. M. C. Rosenberg, and J. I. Bell. 1992. The human T cell receptor in health and disease. Annu. Rev. Immunol. 10:71-96.

32. Pluschke, G., G. Ricken, H. Taube, S. Kroninger, I. Melchers, H. H. Peter K. Eichmann, and U. Krawinkel. 1991. Biased T cell receptor V $\alpha$ region repertoire in the synovial fluid of rheumatoid arthritis patients. Eur. J. Immunol. 21:2749 2754

33. Oksenberg, J. R., S. Stuart, A. B. Begovitch, R. B. Bell, H. A. Ehrlich, L. Steinman, and C. C. A. Bernard. 1990. Limited heterogeneity of rearranged $\mathrm{T}$-cell receptor $\mathrm{V} \boldsymbol{\alpha}$ transcripts in brains of multiple sclerosis patients. Nature (Lond.). 345:344-346.

34. Brendel, V., J. Dohlman, B. E. Blaisdell, and S. Karlin. 1991. Very long charge runs in systemic lupus erythematosus-associated autoantigens. Proc. Natl. Acad. Sci. USA. 88:1536-1540.

35. Harley, J. B., A. L. Sestak, L. G. Willis, S. M. Fu, J. A. Hansen, and M Reichlin. 1989. A model for disease heterogeneity in systemic lupus erythematosus: relationships between histocompatibility antigens, autoantibodies, and lymphopenia or renal disease. Arthritis Rheum. 32:826-836.

36. Wucherpfennig, K. W., K. Ota, N. Endo, J. G. Seidman, A. Rosenzweig H. L. Weiner, and D. A. Hafler. 1990. Shared human T cell receptor V $\beta$ usage to immunodominant regions of myelin basic protein. Science (Wash. DC) 248:1016-1019.

37. Jorgensen, J. L., U. Esser, P. A. Reay, B. Fazekas de St. Groth, and M. M. Davis. 1992. Mapping T cell receptor/peptide contacts by variant peptide immunization of single-chain transgenics. Nature (Lond.). 355:224-230.

38. Danska, J. S., A. M. Livingstone, V. Paragas, T. Ishihara, and C. G. Fathman. 1990. The presumptive CDR3 regions of both T cell receptor $\alpha$ and $\beta$ chains determine T cell specificity for myoglobin peptides. J. Exp. Med. 172:2733.

39. Jaulin, C., J.-L. Casanova, P. Romero, I. Luescher, A.-S. Cordey, J. L. Maryanski, and P. Kourilsky. 1992. Highly diverse T cell recognition of a single Plasmodium berghei peptide presented by a series of mutant $\mathbf{H}-2 \mathrm{Kd}$ molecules. J. Immunol. 149:3990-3994.

40. Chothia, C., D. R. Boswell, and A. M. Lesk. 1988. The outline structure of the T-cell $\alpha \beta$ receptor. EMBO (Eur. Mol. Biol. Organ.) J. 7:3745-3755.

41. Kasibhatla, S., E. A. Nalefski, and A. Rao. 1993. Simultaneous involvement of all six predicted antigen binding loops of the $\mathrm{T}$ cell receptor in recognition of the MHC/antigenic peptide complex. J. Immunol. 151:3140-3151.

42. Utz, U., J. A. Brooks, H. F. McFarland, R. Martin, and W. E. Biddison 1994. Heterogeneity of T-cell receptor $\alpha$-chain CDR3 in myelin basic protein specific T cells increases with severity of multiple sclerosis. Proc. Natl. Acad. Sci. USA. 91:5567-5571.

43. Sainis, K., and S. K. Datta. 1988. CD4+ T cell lines with selective patterns of autoreactivity as well as CD4-/CD8- T helper cell lines augment the production of idiotypes shared by pathogenic anti-DNA autoantibodies in the NZB $x$ SWR model of lupus nephritis. J. Immunol. 140:2215-2224.

44. Lanzavecchia, A. 1985. Antigen-specific interaction between $T$ and $B$ cells. Nature(Lond.). 314:537-539.

45. Lin, R. H., M. J. Mamula, J. A. Hardin, and J. C. A. Janeway. 1991 Induction of autoreactive B cells allows priming of autoreactive T cells. $J$. Exp. Med. 173:1433-1439.

46. Mamula, M. J., S. Fatenejad, and J. Craft. 1994. B cells process and present lupus autoantigens that initiate autoimmune T cell responses. J. Immunol. 152:1453-1461.

47. Reichlin, M., A. Martin, E. Taylor-Albert, K. Tsuzaka, W. Zang, M. W Reichlin, E. Koren, F. M. Ebling, B. Tsao, and B. H. Hahn. 1994. Lupus autoantibodies to native DNA cross-react with A and D SnRNP polypeptides. J. Clin. Invest. 93:443-449.

48. Bloom, D. D., E. W. St. Clair, D. S. Pisetsky, and S. H. Clarke. 1994 The anti-La response of a single MRL/Mp-lpr/lpr mouse: specificity for DNA and VH gene usage. Eur. J. Immunol. 24:1332-1338.

49. Termaat, R. M., K. Brinkman, J. C. Nossent, A. J. G. Swaak, R. J. T. Smeenk, and J. H. M. Berden. 1990. Anti-heparan sulphate reactivity in sera from patients with systemic lupus erythematosus with renal or non-renal manifestations Clin. Exp. Immunol. 82:268-274.

50. Lilley, D. M. J. 1992. HMG has DNA wrapped up. Nature (Lond.) 357:282-283.

51. Portanova, J. P., R. E. Arndt, and B. L. Kotzin. 1988. Selective production of autoantibodies in graft-versus-host induced and spontaneous murine lupus. Predominant reactivity with histone regions accessible in chromatin. J. Immunol. 140:755-760.

52. Lake, P., and N. A. Mitchison. 1976. Regulatory mechanisms in the immune response to cell-surface antigens. Cold Spring Harbor Symp. Quant. Biol. 41:589-595

53. Lehman, P., T. Forsthuber, A. Miller, and E. Sercarz. 1992. Spreading of 
T cell autoimmunity to cryptic determinants of an autoantigen. Nature (Lond.). 358:155-157.

54. Ganju, R. K., S. T. Smiley, J. Bajorath, J. Novotny, and E. L. Reinherz 1992. Similarity between fluorescein-specific T-cell receptor and antibody in chemical details of antigen recognition. Proc. Natl. Acad. Sci. USA. 89:1155211556

55. Constant, P., F. Davodeau, M.-A. Peyrat, Y. Poquet, G. Puzo, M. Bonneville, and J.-J. Fournie. 1994. Stimulation of human $\gamma / \delta \mathrm{T}$ cells by nonpeptidic mycobacterial ligands. Science (Wash. DC). 264:267-270.

56. Carson, D. A. 1991. The specificity of anti-DNA antibodies in systemic lupus erythematosus. J. Immunol. 146:1-3.

57. Freed, A. C., S. H. Hefeneider, C. Vedder, K. Khaw, A. C. Bakke, S. L. McCoy, and R. M. Bennett. 1994. Partial cloning and expression of a cell-surface glycoprotein which binds DNA and nucleosomes. Arthritis Rheum. 37(Suppl. 6):R5. (Abstr.)

58. Burlingame, R. W., R. L. Rubin, R. S. Balderas, and A. N. Theofilopoulos. 1993. Genesis and evolution of anti-chromatin autoantibodies in murine lupus implicates immunization with self antigen. J. Clin. Invest. 91:1687-1696.

59. Jacob, L., J. P. Viard, B. Allenet, M. F. Anin, F. B. H. Slama, J. Vandekerckhove, J. Primo, J. Markovits, F. Jacob, J. F. Bach, J. B. LePecq, and D. Louvard. 1989. A monoclonal anti-double stranded DNA autoantibody binds to a $94 \mathrm{kDa}$ cell-surface protein on various cell types via nucleosomes or a DNAhistone complex. Proc. Natl. Acad. Sci. USA. 86:4669-4673.

60. Casciola-Rosen, L. A., G. Anhalt, and A. Rosen. 1994. Autoantigens targeted in systemic lupus erythematosus are clustered in two populations of surface structures on apoptotic keratinocytes. J. Exp. Med. 179:1317-1330.

61. Rumore, P., and C. Steinman. 1990. Endogenous circulating DNA in systemic lupus erythematosus. Occurrences as multimeric complexes bound to histones. J. Clin. Invest. 86:69-74.

62. Fournie, G. J., J. Lule, J.-M. Dueymes, F. Laval, I. Deloble, I. Vernier, and J. P. Pourat. 1989. Plasma DNA in patients undergoing hemodialysis at hemofiltration: cytolysis in artificial kidney is responsible for the release of DNA in circulation. Am. J. Nephrol. 9:384-391.
63. Desai, D. D., M. R. Krishnan, J. T. Swindle, and T. N. Marion. 1993. Antigen-specific induction of antibodies against native mammalian DNA in nonautoimmune mice. J. Immunol. 151:1614-1626.

64. Kanai, Y., O. Takeda, Y. Kanai, K. Miura, and Y. Kurosawa. 1994. Novel autoimmune phenomena induced in vivo by a new DNA binding protein Nuc: a study on MRL/n mice. Immunol. Lett. 39:83-89.

65. Fredriksen, K., A. Osei, A. Sundsfjord, T. Traavik, and O. P. Rekvig. 1994 On the biological origin of anti-dsDNA antibodies: systemic lupus erythematosus related anti-dsDNA antibodies are induced by polyomavirus BK in lupus-prone (NZB x NZW)F1 hybrids, but not in normal mice. Eur. J. Immunol. 24:66-70.

66. Shoenfeld, Y., J. Rauch, H. Massicote, S. K. Datta, J. Andre-Schwartz B. D. Stollar, and R. S. Schwartz. 1983. Polyspecificity of monoclonal lupus autoantibodies produced by human-human hybridomas. N. Engl. J. Med. 308:414420.

67. Ando, D. G., E. E. Sercarz, and B. H. Hahn. 1987. Mechanisms of T and $B$ cell collaboration in the in vitro production of anti-DNA antibodies in the NZB NZW F1 murine SLE model. J. Immunol. 138:3185-3190.

68. Sobel, E. S., V. N. Kakkanaiah, M. Kakkanaiah, R. L. Cheek, P. L. Cohen, and R. A. Eisenberg. 1994. T-B collaboration for autoantibody production in lpr mice is cognate and MHC-restricted. J. Immunol. 152:6011-6016.

69. Naiki, M., B.-L. Chiang, D. Cawley, A. Ansari, S. J. Rozzo, B. L. Kotzin A. Zlotnik, and M. E. Gershwin. 1992. Generation and characterization of cloned helper $\mathrm{T}$ cell lines for anti-DNA responses in NZB.H-2 ${ }^{\mathrm{bm} / 2}$ mice. J. Immunol. 149:4109-4115.

70. Crow, M. K., G. DelGuidice-Asch, J. B. Zehetbauer, J. L. Lawson, N. Brot, H. Weissbach, and K. B. Elkon. 1994. Autoantigen-specific T cell proliferation induced by ribosomal $\mathrm{P} 2$ protein in patients with systemic lupus erythematosus. J. Clin. Invest. 94:345-352.

71. Hoffman, R. W., T. Yoshihiko, G. C. Sharp, D. R. Lee, D. L. Hill, H. Kaneoka, and C. W. Caldwell. 1993. Human T cell clones reactive against U-small nuclear ribonucleoprotein autoantigens from connective tissue disease patients and healthy individuals. J. Immunol. 157:6460-6467. 